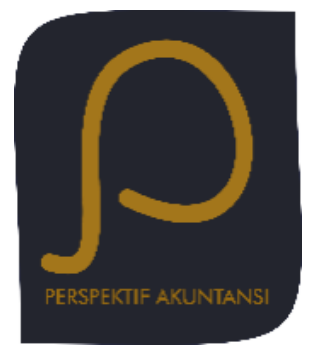

Perspektif Akuntansi

Volume 2 Nomor 2 (Juni 2019), hal. 195-222

ISSN: 2623-0194 (Print), 2623-0186 (Online)

Copyright(C) The Authors(s). All Rights Reserved

Fakultas Ekonomika dan Bisnis,

Universitas Kristen Satya Wacana

DOI: https://doi.org/10.24246/persi.v1i2.p195-222

http://ejournal.uksw.edu/persi

\title{
Determinan Kualitas Pengungkapan Lingkungan dan Pengaruhnya Terhadap Nilai Perusahaan
}

\author{
Wihelmina Dea Kosasih ${ }^{1}$ \\ Universitas Ma Chung \\ Daniel Sugama Stephanus \\ Universitas Ma Chung \\ Putu Indrajaya Lembut \\ Universitas Ma Chung
}

Received

10 Juni 2019

Accepted

20 Juli 2019

\begin{abstract}
This study aims to prove the influence of environmental performance, industry sensitivity, corporate governance structure and media coverage on the quality of environmental disclosures, also aims to prove the influence of the quality of environmental disclosure on the value of the company. The sample in this study were companies registered in eight types of industries, namely mining, energy, chemistry, pharmacy, cosmetics and household needs, food and beverages, oil and gas, and forestry in the period 2015-2017. This study uses Principal Component Analysis (PCA) to simplify corporate governance structure variables. The results show one component that represents corporate governance, the size of the board of commissioners, audit committee, and institutional ownership. Further, the results also indicate that environmental performance, industry sensitivity, corporate governance structure, media coverage and profitability have a positive effect on the quality of environmental disclosures.
\end{abstract}

Keywords: quality of environmental disclosures, environmental performance, industry sensitivity, corporate governance structure, media coverage

Abstrak. Penelitian ini bertujuan untuk membuktikan pengaruh kinerja lingkungan, sensitivitas industri, struktur tata kelola perusahaan dan

${ }^{1}$ wihelminadea@gmail.com 


\begin{abstract}
liputan media terhadap kualitas pengungkapan lingkungan,serta bertujuan untuk membuktikan pengaruh kualitas pengungkapan lingkungan terhadap nilai perusahaan. Sampel dalam penelitian ini adalah perusahaan yang terdaftar di delapan jenis industri, yaitu pertambangan, energi, kimia, farmasi, kosmetik dan kebutuhan rumah tangga, makanan dan minuman, minyak dan gas, dan kehutanan pada periode 2015-2017. Penelitian ini menggunakan Principal Component Analysis (PCA) untuk menyederhanakan variabel struktur tata kelola perusahaan. Hasil menunjukkan ada satu komponen yang dapat mewakili tata kelola perusahaan, yaitu ukuran dewan komisaris, komite audit, dan kepemilikan institusional. Hasil penelitian ini menunjukkan bahwa kinerja lingkungan, sensitivitas industri, struktur tata kelola perusahaan, liputan media dan profitabilitas memiliki efek positif pada kualitas pengungkapan lingkungan.
\end{abstract}

Kata kunci kualitas pengungkapan lingkungan, kinerja lingkungan, sensitivitas industry, struktur tata kelola, liputan media

\title{
Pendahuluan
}

Perusahaan tidak lagi bertanggung jawab pada nilai perusahaan yang dicerminkan dalam kondisi keuangan saja, namun juga harus memperhatikan aspek sosial dan lingkungan tempat perusahaan itu berada (Yanti, 2015). Salah satunya dikarenakan oleh kondisi lingkungan Indonesia yang darurat ekologis. Indonesia masih darurat ekologis dikarenakan bencana ekologis seperti banjir, tanah longsor, kebakaran hutan, dan kekeringan masih terjadi di sepanjang tahun dan intensitasnya terus meningkat.

Berdasarkan data Badan Nasional Penanggulangan Bencana (BNPB), telah terjadi peningkatan bencana alam sebesar 1.168 kejadian di tahun 2015-2017. Berdasarkan data tersebut sebesar $99,08 \%$ bencana alam adalah bencana ekologis (Mongabay, 2018). Penyebab utamanya bencana ekologis adalah kerusakan lingkungan yang masif akibat menurunnya kepedulian pada lingkungan (KOMPAS, 2017). Aktivitas monopoli perusahaan pada sumber daya alam secara tidak ramah lingkungan juga berkontribusi pada terjadi bencana ekologis (Mongabay, 2018).

Hasil survei dari Wahana Lingkungan Hidup Indonesia (WALHI) pada tahun 2014 menyatakan penyebab banyaknya kasus lingkungan diakibatkan masih minimnya pelaporan tanggung jawab lingkungan yang dilakukan perusahaan. Dengan demikian, pengungkapan lingkungan secara berkualitas perlu dilakukan oleh setiap perusahaan. Hasil penelitian Safitri (2013) pada sektor industri dasar dan kimia menunjukkan bahwa pengungkapan pada kategori lingkungan memperoleh persentase pelaporan yang paling sedikit dari kedua kategori yang lain yaitu ekonomi dan sosial. Sedangkan di Indonesia, aktivitas lingkungan perusahaan merupakan topik utama yang sering dipublikasikan. 
Pelaksanaan pengungkapan lingkungan perusahaan adalah hal yang wajib dilakukan perusahaan sesuai dengan ketentuan Keputusan Ketua Badan Pengawas Pasar Modal dan Lembaga Keuangan No. KEP-431/BL/2012. Pada pasal 66 ayat 2c menyatakan bahwa perusahaan publik dalam melaporkan laporan tahunan wajib memuat salah satunya tanggung jawab sosial dan lingkungan perusahaan. Dengan demikian, perusahaan diwajibkan salah satunya melaporkan tanggung jawab lingkungan perusahaan. Namun, luas pengungkapan minimum dan aturan resmi dalam penyajian dari aktivitas tanggung jawab lingkungan belum diatur dalam ketentuan tersebut. Sebagian besar perusahaan memutuskan sendiri bentuk laporan dan seberapa banyak pengungkapan lingkungan yang akan dipublikasikan. Oleh karenanya pengungkapan lingkungan masih bervariasi bergantung pada kebijakan perusahaan tersebut.

Luas pengungkapan lingkungan yang akan dipublikasikan diputuskan oleh pihak manajerial dan ditujukan kepada board of directors dan shareholders (Millstein, 1991). Konsep corporate governance yang dianut di Indonesia adalah sistem two tier. Sistem two tier memisahkan fungsi pengawas dan pelaksanaan sehingga terdapat dewan komisaris dan dewan direksi dalam perusahaan (FCGI, 2001). Penerapan mekanisme corporate governance terbagi menjadi dua yaitu mekanisme internal dan eksternal (Barnhart dan Rosenstein, 1998). Salah satu mekanisme internal dalam prinsip corporate governance adalah dewan komisaris. Board of directors (dewan komisaris) memunyai peran pengawasan dan memberikan arahan manajer dalam pengelolan perusahaan. Adanya dewan komisaris dalam perusahaan sebagai wakil dari para shareholder dapat mengawasi dari pihak manajemen dalam melaksanakan tugasnya. Sehingga, para shareholder dapat mendapatkan hak-haknya, salah satunya laporan pengungkapan lingkungan mengenai tanggung jawab perusahaan terhadap lingkungan.

Keefektifan peran dewan komisaris dapat dilihat dari komposisi keanggotaannya yang dapat dilihat dari karakteristik dewan. Komisaris independen, keberagaman gender, multiple-directorship dan ukuran dewan komisaris merupakan karakteristik dewan yang dapat meningkatkan keefektifan peran dewan komisaris. Pihak dewan komisaris dibantu oleh komite-komite dalam menjalankan tugasnya, salah satunya adalah komite audit. Komite audit berperan dalam proses pelaporan keuangan, sehingga keberadaannya dapat memastikan pengungkapan telah dilakukan termasuk pengungkapan lingkungan. komite audit berkaitan dengan pengungkapan lingkungan.

Pihak manajer juga berperan penting dalam pengungkapan lingkungan. Manajemen bertugas dalam pembuatan dan pengungkapan laporan tahunan. 
Oleh karenanya, semakin besar kepemilikan manajer akan semakin banyak mengungkapkan informasi lingkungan yang akan diungkapkan. Hal ini disebabkan karena manajer yang memiliki kepemilikan saham perusahaan akan menyesuaikan kepentingannya dengan kepentingan perusahaan (Oktafianti dan Rizki, 2015). Sedangkan, mekanisme eksternal dalam prinsip corporate governance salah satunya adalah adanya kepemilikan oleh investor institusional. Kepemilikan institusional dapat mengurangi agency problem dengan melakukan pengawasan. Keberadaan investor institusional dapat memaksimalkan pengawasan manajemen pada setiap keputusan yang diambil manajemen untuk perusahaan (Wiranata dan Nugrahanti, 2013).

Laporan yang berisikan pengungkapan lingkungan tidak hanya ditujukan kepada shareholder saja. Namun, ditujukan kepada pihak yang lebih luas yaitu stakeholder yang terdiri dari shareholder dan non-shareholder (Prasetianti, 2014). Pihak-pihak non-shareholder ini seperti masyarakat umum, pemerintah, regulator, atau media. Pengungkapan kepada pihak non-shareholder dilakukan untuk mendapatkan legitimasi. Perusahaan dalam mendapatkan legitimasi melakukan komunikasi, komunikasi ini dapat dilakukan melalui pengungkapan salah satunya dalam media (Solikhah dan Winarsih, 2016).

Pemerintah sebagai pihak non-shareholder mengapresiasi perusahaan yang memiliki kinerja lingkungan yang baik melalui PROPER. Pemerintah melalui Kementerian Lingkungan Hidup mengadakan PROPER yaitu pemeringkatan kinerja lingkungan perusahaan untuk meningkatkan peran perusahaan dalam melestarikan lingkungan hidup. Apabila suatu perusahaan memiliki kinerja lingkungan yang baik, maka perusahaan akan melakukan pengungkapan lingkungan dalam laporan tahunannya (Aulia dan Agustina, 2015).

Pengungkapan lingkungan juga bergantung pada seberapa peka dampak aktifitas operasional perusahaan terhadap lingkungan. Perusahaan yang memiliki dampak besar terhadap lingkungan termasuk dalam high profile karena dampak aktifitas operasionalnya memiliki dampak besar terhadap kerusakan lingkungan. Sedangkan, perusahaan low profile aktifitas operasionalnya tidak seberapa berdampak pada lingkungan. Dengan demikian, perusahaan high profile perlu melakukan pengungkapan lingkungan secara lebih berkualitas untuk mendapatkan legitimasi.

Penelitian ini menggunakan kualitas pengungkapan lingkungan sebagai variabel dependen. Variabel kualitas pengungkapan lingkungan ini sesuai dengan indikator kualitas pengungkapan lingkungan dalam penelitian Rupley et al., (2012) yang terdiri atas compliance, pollution prevention, product stewardship, dan sustainable development. Compliance yaitu tingkat kepatuhan perusahaan dalam pengungkapan lingkungan. Pollution prevention yaitu 
tingkat perusahaan dalam meminimalisir polusi terhadap lingkungan. Product stewardship yaitu perusahaan dalam aktifitas produksi menggunakan bahanbahan ramah lingkungan dan bahan daur ulang. Sustainable development, perusahaan telah menyajikan ketiga kategori pengungkapan lingkungan dan telah melakukan tanggung jawab terhadap lingkungan secara berkelanjutan seiring dengan pertumbuhan perusahaan (Solikhah dan Winarsih, 2016).

Perusahaan yang melakukan pengungkapan lingkungan secara berkualitas akan mendapatkan manfaat yaitu peningkatan nilai perusahaan. Hal ini dikarenakan perusahaan telah menyediakan informasi yang berguna bagi stakeholder secara lebih luas. Khususnya, tentang respon perusahaan terhadap permasalahan lingkungan yang ada di masyarakat untuk melaksanakan bisnis yang bertanggung jawab terhadap lingkungan (Hahn dan Kühnen, 2013). Dengan demikian, pengungkapan lingkungan yang semakin berkualitas dapat menarik dan mempengaruhi persepsi investor, yang menguntungkan secara ekonomi perusahaan dan, pada akhirnya, akan tercermin dalam nilai perusahaan (Deswanto dan Siregar, 2018).

Hasil penelitian Solikhah dan Winarsih (2016) menunjukkan variabel independen kepekaan industri, multiple directorships, ukuran dewan komisaris, serta variabel kontrol ukuran perusahaan, dan profitabilitas berpengaruh terhadap kualitas pengungkapan lingkungan. Sedangkan, variabel liputan media, keragaman gender, komisaris independen, dan kepemilikan institusional tidak berpengaruh terhadap kualitas pengungkapan lingkungan. Kemudian, penelitian Rupley et al., (2012) menunjukkan hasil keberadaan liputan media, dewan komisaris independen, keberagaman gender, multipledirectorship, berpengaruh positif terhadap kualitas pengungkapan lingkungan. Hal ini menunjukkan masih banyak perbedaan-perbedaan hasil penelitian serta adanya keterbatasan dalam penelitian sebelumnya terkait dengan kualitas pengungkapan lingkungan.

Pengaruh kualitas pengungkapan lingkungan terhadap nilai perusahaan juga belum mendapatkan hasil yang konsisten. Hasil penelitian Plumlee et al., (2015) menunjukkan kualitas pengungkapan lingkungan berpengaruh terhadap nilai perusahaan. Sejalan dengan penelitian Radhouane et al., (2018) yang menunjukkan pengungkapan lingkungan berpengaruh terhadap nilai perusahaan. Namun, berbeda dengan penelitian Deswanto dan Siregar (2018), yang menunjukkan hasil pengungkapan lingkungan tidak berpengaruh terhadap nilai perusahaan.

Penelitian ini memodifikasi penelitian Solikhah dan Winarsih (2016) dengan menambahkan beberapa aspek yang berbeda. Pertama, penelitian ini menggunakan Principal Component Analysis (PCA) untuk menyederhanakan 
variabel struktur tata kelola perusahaan. Kemudian penambahan dua variabel dalam penelitian ini yaitu kepemilikan manajerial dan komite audit sebagai variabel dalam struktur tata kelola perusahaan. Kedua, penelitian ini menambahkan variabel independen yaitu kinerja lingkungan yang diperkirakan akan berpengaruh pada kualitas pengungkapan lingkungan. Ketiga, penelitian ini menambahkan uji pengaruh kualitas pengungkapan lingkungan terhadap nilai perusahaan. Keempat, kualitas pengungkapan lingkungan pada penelitian ini mengacu pada penelitian Rupley, et al., (2012) yang telah memodifikasi pengungkapan lingkungan dari GRI. Selain itu, kualitas pengungkapan lingkungan diukur dalam penelitian ini menggunakan skala scoring untuk setiap item kriteria. Item 0 jika tidak diungkapkan, 1 jika diungkapkan dalam narasi, dan 2 jika diungkapkan dalam narasi dan angka untuk meminimalisasi unsur subjektivitas. Kelima, penelitian ini menambahkan dua sektor baru yaitu minyak dan gas, dan perhutanan yang aktivitas perusahaannya berhubungan langsung dengan alam serta periode penelitian yang berbeda yaitu pada tahun 2015-2017.

Penelitian ini ditujukan untuk membuktikan apakah kinerja lingkungan, kepekaan industri, struktur tata kelola perusahaan, dan liputan media berpengaruh terhadap kualitas pengungkapan lingkungan. Kemudian, penelitian ini juga membuktikan pengaruh kualitas pengungkapan lingkungan terhadap nilai perusahaan. Penelitian mengenai pengaruh kinerja lingkungan, kepekaan industri, struktur tata kelola perusahaan dan media belum menemukan hasil yang konsisten. Dengan demikian, diharapkan melalui penelitian ini dapat memberikan hasil yang konsisten sebagai kontribusi bahan referensi mengenai pengaruh kinerja lingkungan, kepekaan industri, struktur tata kelola perusahaan, dan media terhadap kualitas pengungkapan lingkungan.

\section{Telaah Pustaka}

Berdasarkan teori kegenan, dalam menjalankan aktifitas operasional, perusahaan terdapat perbedaan kepentingan antara pihak pemilik dan manajer. Perbedaan kepentingan ini merupakan agency problem yang terjadi dikarenakan pemilik dan manajer memiliki tujuan yang berbeda dalam menjalankan perannya (Jensen \& Meckling, 1976). Adanya perbedaan kepentingan pemilik dan manajer dapat menimbulkan terjadinya asimetri informasi ketika manajer memunyai informasi mengenai perusahaan yang lebih besar dari pada pemilik perusahaan. Perusahaan dalam meminimalkan asimetri informasi dapat meningkatkan transparansi. Peningkatan transparansi melalui pengungkapan yang lebih luas termasuk pengungkapan 
lingkungan dapat menyesuaikan kepentingan manajer dan pemilik (Jensen \& Meckling, 1976).

Pengungkapan tanggung jawab lingkungan perusahaan secara berkualitas akan memberikan dampak yang baik bagi perusahaan yaitu adanya legitimasi dari masyarakat. Hal ini dikarenakan perusahaan telah bertanggung jawab atas dampak aktifitas operasional yang ditimbulkan dari perusahaan dan peduli pada masalah lingkungan yang ada di sekitar perusahaan yang dapat ditunjukkan melalui laporan pengungkapan lingkungan perusahaan. Laporan yang berisikan pengungkapan lingkungan tidak hanya ditujukan kepada shareholder saja. Namun, laporan tersebut juga ditujukan kepada nonshareholder. Pihak shareholder diwakili oleh dewan komisaris, kepemilikan manajerial, komite audit, dan kepemilikan institusional yang merupakan bagian dari corporate governance. Adanya corporate governance akan meminimalkan konflik manajer dan pemilik. Hal ini karena kinerja manajer akan diawasi, sehingga agen tersebut akan bekerja sesuai sistem pengendalian yang ada.

Sedangkan, kinerja lingkungan dan liputan media yang digunakan dalam penelitian ini mewakili non-shareholder yaitu masyarakat dan stakeholder lainnya. Liputan media dapat menjadi pihak eksternal yang mewakili dari masyarakat melalui pemberitaan-pemberitaan. Begitu pula, pemerintah sebagai salah satu pihak non-shareholder mengapresiasi perusahaan yang memiliki kinerja lingkungan yang baik melalui PROPER yang merupakan pemeringkatan kinerja lingkungan oleh Kementerian Lingkungan Hidup yang diperkirakan akan berpengaruh pada kualitas pengungkapan lingkungan.

Selain mendapatkan legitimasi, perusahaan yang mengungkapkan pengungkapan lingkungan yang berkualitas semakin memiliki nilai perusahaan yang baik. Pengungkapan tanggung jawab lingkungan dapat berkontribusi pada nilai perusahaan, karena menyediakan informasi yang berguna kepada kelompok pemangku kepentingan yang lebih luas dan dengan demikian dapat memenuhi kebutuhan informasi stakeholder. Khususnya informasi tentang bagaimana perusahaan merespon permasalahan lingkungan di masyarakat untuk melaksanakan bisnis yang peduli terhadap lingkungan.

\section{Pengembangan hipotesis}

\section{Pengaruh Kinerja Lingkungan terhadap Kualitas Pengungkapan Lingkungan}

Berdasarkan teori legitimasi, legitimasi adalah penerimaan keberadaan perusahaan di sekitar masyarakat tempat perusahaan berada. Perusahaan untuk dapat diterima masyarakat, harus dapat menyesuaikan tujuan ekonomi 
perusahaan dengan tujuan sosial dan lingkungan (Hariati dan Rihatiningtyas, 2015). Kinerja lingkungan merupakan upaya perusahaan dalam meminimalisir dampak yang terjadi oleh akibat aktivitas operasional perusahaan dalam rangka mendapatkan legitimasi untuk keberlangsungan usahanya.

Ketika suatu perusahaan memiliki kinerja lingkungan yang baik, maka perusahaan akan mengungkapkannya dalam laporan tahunannya (Aulia dan Agustina, 2015). Oleh karenanya, jika perusahaan memunyai kinerja lingkungan baik maka kualitas pengungkapan lingkungan perusahaan juga akan lebih baik. Kinerja lingkungan perusahaan perlu untuk diungkapkan dikarenakan melalui laporan tersebut para stakeholder dapat mengetahui tanggung jawab dari perusahaan.

Hasil penelitian dari Aulia dan Agustina (2015) menunjukkan kinerja lingkungan berpengaruh terhadap environmental disclosure. Sejalan dengan penelitian Wulandari dan Puspaningsih (2017) yang menunjukkan kinerja lingkungan secara positif berpengaruh terhadap corporate social responsibility. Sedangkan penelitian, Sukasih dan Sugiyanto (2017) menunjukkan hasil kinerja lingkungan yang diukur dengan peringkat PROPER tidak berpengaruh signifikan terhadap corporate social responsibility.

$\mathrm{H}_{1}$ : kinerja lingkungan berpengaruh positif terhadap kualitas pengungkapan lingkungan.

\section{Pengaruh Kepekaan Industri terhadap Kualitas Pengungkapan Lingkungan}

Berdasarkan teori legitimasi, perusahaan yang memunyai dampak besar terhadap lingkungan akan semakin dituntut masyarakat dalam mengungkapkan informasi lingkungan secara berkualitas (Solikhah dan Winarsih, 2016). Perusahaan yang memunyai dampak besar terhadap lingkungan termasuk kategori high profile. Perusahaan high profile akan lebih mendapatkan sorotan dari masyarakat daripada perusahaan low profile karena dampak aktifitas operasional perusahaan yang memiliki potensi berhubungan dengan kepentingan masyarakat luas (Purwanto, 2010).

Di Indonesia, perusahaan yang mendapat sorotan dari masyarakat karena aktivitas operasionalnya yang berpotensi merusak alam adalah perusahaan tambang (Sari, 2012). Akibat dampak aktivitas operasional perusahaan tambang, perusahaan tambang semakin dituntut masyarakat dalam melakukan pertanggungjawaban pada lingkungan. Pertangunggjawaban tersebut dapat diungkapkan dalam laporan tahunan agar mendapatkan legitimasi dari para stakeholder demi keberlangsungan usahanya. Hasil penelitian dari Rupley, et 
al., (2012) dan Solikhah dan Winarsih (2016) menunjukkan bahwa kepekaan industri berpengaruh positif terhadap kualitas pengungkapan lingkungan.

$\mathrm{H}_{2}$ : Kepekaan industri berpengaruh positif terhadap kualitas pengungkapan lingkungan.

\section{Pengaruh Struktur Tata Kelola Perusahaan terhadap Kualitas Pengungkapan Lingkungan}

Menurut teori agensi, dalam aktifitas operasional perusahaan terdapat perbedaan kepentingan yang terjadi di antara manajer dan pemilik yang dapat menimbulkan agency problem (Jensen dan Meckling, 1976). Konflik kepentingan ini disebabkan oleh perbedaan tujuan manajer dan pemilik yang dapat memicu terjadinya asimetri informasi. Asimetri informasi terjadi saat manajer memunyai informasi mengenai perusahaan yang lebih banyak dari pada pemilik.

Penerapan corporate governance dalam perusahaan dapat meminimalkan adanya agency problem. Penerapan mekanisme corporate governance dapat meningkatkan monitoring terhadap tindakan manajemen (Rebecca dan Siregar, 2012). Perusahaan yang menerapkan prinsip corporate governance akan meningkatkan dari transparansi salah satunya pengungkapan lingkungan untuk meminimalkan asimetri informasi.

Hasil penelitian Solikhah dan Winarsih (2016) menunjukkan komisaris independen, multiple directorships, ukuran dewan komisaris berpengaruh terhadap kualitas pengungkapan lingkungan. Sedangkan, variabel keragaman gender dan kepemilikan institusional tidak berpengaruh terhadap kualitas pengungkapan lingkungan. Pada penelitian Rupley et al., (2012) menguji struktur tata kelola perusahaan terhadap kualitas pengungkapan lingkungan. Hasil menunjukkan hasil dewan komisaris independen, keberagaman gender, dan multiple-directorship berpengaruh positif terhadap kualitas pengungkapan lingkungan. Sedangkan variabel pemisahan CEO dari posisi ketua dewan, komite tanggung jawab sosial perusahaan dan investor institusional tidak berpengaruh terhadap kualitas pengungkapan lingkungan.

$\mathrm{H}_{3}$ : Struktur tata kelola perusahaan berpengaruh positif terhadap kualitas pengungkapan lingkungan.

\section{Pengaruh Liputan Media terhadap Kualitas Pengungkapan Lingkungan}

Berdasarkan teori legitimasi, perusahaan merupakan unit sosial. Oleh karenanya, apabila perusahaan ingin menjaga keberlangsungannya, maka perusahaan harus memerhatikan norma serta keadaan sosial dan lingkungan tempat beroperasi (Anggraeni dan Djakman, 2017). Legitimasi merupakan hal 
penting karena berhubungan dengan kelangsungan hidup perusahaan. Legitimasi perusahaan dapat diperoleh dengan berbagai cara, salah satunya melakukan komunikasi kepada para stakeholder (Ashforth dan Gibbs, 1990 dalam Solikhah dan Winarsih, 2016).

Liputan media merupakan hal yang dapat memengaruhi dari pandangan masyarakat terhadap perusahaan. Salah satu pemberitaan yang sering dipublikasikan mengenai perusahaan adalah dampak aktifitas perusahaan terhadap lingkungan. Peningkatan liputan media mengenai dampak aktifitas perusahaan terhadap lingkungan didorong oleh meningkatnya kepedulian masyarakat terhadap lingkungan hidup (Aulia dan Agustina, 2015). Penelitian Rupley et al., (2012) dan Aulia dan Agustina (2015) menunjukkan bahwa variabel liputan media berpengaruh signifikan terhadap environmental disclosures. Berbeda dengan penelitian Hadjoh dan Sukartha (2013) dan Solikhah dan Winarsih (2016) yang menunjukkan eksposur media tidak berpengaruh pada pengungkapan lingkungan.

$\mathrm{H}_{4}$ : Liputan media berpengaruh positif terhadap kualitas pengungkapan lingkungan.

\section{Pengaruh Kualitas Pengungkapan Lingkungan terhadap Nilai Perusahaan}

Berdasarkan teori legitimasi, legitimasi adalah penerimaan keberadaan perusahaan di sekitar masyarakat tempat perusahaan berada. Untuk dapat diterima masyarakat, organisasi harus dapat menyelaraskan antara tujuan ekonomi dengan tujuan lingkungan dan sosialnya. Pengungkapan lingkungan adalah upaya perusahaan dalam menyelaraskan lingkungan dengan dampak negatif akibat kegiatan operasional perusahaan. Selain itu, untuk meminimalkan asimetri informasi dalam perusahaan dapat mengungkapkan pelaporan yang lebih luas termasuk pengungkapan lingkungan.

Pengungkapan tanggung jawab lingkungan dapat berkontribusi pada nilai perusahaan oleh karena menyediakan informasi yang berguna kepada kelompok pemangku kepentingan secara lebih luas dan dengan demikian dapat memenuhi kebutuhan informasi stakeholder, khususnya tentang bagaimana perusahaan merespon permasalahan lingkungan yang ada di masyarakat untuk melaksanakan bisnis yang bertanggung jawab terhadap lingkungan (Hahn dan Kühnen, 2013).

Hasil penelitian Plumlee et al., (2015) menunjukkan bahwa kualitas pengungkapan lingkungan berpengaruh terhadap nilai perusahaan. Sejalan dengan penelitian Radhouane et al., (2018) yang menunjukkan hasil pengungkapan lingkungan berpengaruh positif terhadap nilai perusahaan. Sedangkan penelitian Deswanto dan Siregar (2018) menunjukkan hasil pengungkapan lingkungan tidak berpengaruh terhadap nilai perusahaan. 
$\mathrm{H}_{5}$ : Kualitas pengungkapan lingkungan berpengaruh positif terhadap nilai perusahaan.

\section{Metoda}

\section{Jenis dan Sumber Data}

Jenis data dalam penelitian ini merupakan data kuantitatif. Sumber data adalah data sekunder. Data kuantitatif yang digunakan adalah annual report, sustainability report, laporan penilaian PROPER oleh pemerintah dan berita mengenai lingkungan hidup baik dari media nasional dan media lingkungan.

\section{Populasi dan Sampel}

Populasi yang digunakan adalah perusahaan yang terdaftar di Bursa Efek Indonesia (BEI) selama periode tahun 2015-2017. Sampel yang digunakan adalah perusahaan yang terdaftar dalam delapan jenis industri yaitu pertambangan, energi, kimia, farmasi, kosmetik dan keperluan rumah tangga, makanan dan minuman, minyak dan gas, dan perhutanan pada periode tahun 2015-2017. Adapun kriteria pemilihan sampel yang digunakan yaitu (1) perusahaan yang terdaftar dalam industri pertambangan, energi, kimia, farmasi, kosmetik dan keperluan rumah tangga, makanan dan minuman, minyak dan gas, dan perhutanan di Bursa Efek Indonesia secara berturut-turut pada periode tahun 2015-2017, (2) perusahaan terdaftar dalam industri pertambangan, energi, kimia, farmasi, kosmetik dan keperluan rumah tangga, makanan dan minuman, minyak dan gas, dan perhutanan yang melaporkan laporan corporate social responsibility baik dalam annual report maupun sustainability report secara berturut-turut pada pada periode tahun 2015-2017, (3) perusahaan industri pertambangan, energi, kimia, farmasi, kosmetik dan keperluan rumah tangga, makanan dan minuman, minyak dan gas, dan perhutanan yang mengikuti program PROPER pada periode tahun 2015-2017.

\section{Definisi Operasional Variabel}

\section{Variabel Dependen ( $Y$ )}

Kualitas Pengungkapan Lingkungan Pengukuran variabel kualitas pengungkapan lingkungan mengacu pada indeks Rupley et al., (2012) yaitu menggunakan index scorecard pengungkapan lingkungan yang terdiri dari 60 item pengungkapan lingkungan yang terbagi menjadi empat tingkatan kategori strategi yaitu compliance, pollution prevention, product stewardship, dan sustainable development. Serta, variabel kualitas pengungkapan lingkungan menggunakan prosedur scoring untuk setiap pokok kriteria yaitu 0 jika pokok tidak diungkapkan, 1 jika pokok diungkapkan dalam narasi, dan 2 jika pokok diungkapkan dalam narasi dan angka. 
DQ_QUALITY ${ }_{i t}=$ Skor indikator environmental disclosure

Nilai Perusahaan Nilai perusahaan adalah tujuan utama perusahaan yang dapat mencerminkan kesejahteraan pemegang saham (Cheryta, et al., 2018).

$\mathrm{Q}=\frac{(T M V+D E B T)}{T A} \times 100 \%$

Keterangan:

Q : Nilai Perusahaan

TMV : Total Market Value of Firm

DEBT : Total Nilai Buku dari Utang

TA : Total Nilai Buku Aset

\section{Variabel Independen $(X)$}

Kinerja Lingkungan Kinerja lingkungan merupakan peringkat PROPER yang diterima perusahaan.

Emas : Sangat-sangat baik, skor $=5$

Hijau : Sangat baik, skor $=4$

Biru : Baik, skor $=3$

Merah : Buruk, skor $=2$

Hitam : Sangat buruk, skor $=1$

Kepekaaan Industri Kepekaan industri adalah dampak aktifitas operasional ditimbulkan perusahaan.

0 : Jika perusahaan merupakan industri pertambangan.

1 : Jika perusahaan energi, kimia, farmasi, kosmetik dan keperluan rumah tangga, makanan dan minuman, minyak dan gas, dan perhutanan.

Selanjutnya, struktur tata kelola perusahaan dalam penelitian ini diwakili dengan tujuh variabel yaitu dewan komisaris independen, keragaman gender, multiple directorship, ukuran dewan komisaris, kepemilikan manajerial, komite audit, dan kepemilikan institusional.

Dewan Komisaris Independen

$\mathrm{IND}_{i t}=\frac{\text { Jumlah ang gota dewan } \text { komisaris independen }}{\text { Jumlah seluruh anggota dewan komisaris }}$

Keberagaman Gender

GENDER $_{\text {it }}=$ Jumlah dewan komisaris wanita di perusahaan

Multiple Directorship

DIRECTORSHIP $_{\text {it }}=$ Anggota dewan komisari yang menjabat sebagai dewan komisaris pada perusahaan lain 
Ukuran Dewan Komisaris

$\mathrm{BS}_{\mathrm{it}}=$ Jumlah anggota dewan komisaris

Kepemilikan Manajerial Kepemilikan manajerial diukur berdasarkan jumlah saham yang dimiliki manajer.

KMit $=\frac{\text { Jumlah saham yang dimiliki manajer }}{\text { jumlah saham }}$ XTotal

Komite Audit

KAIit $=$ Jumlah anggota komite audit dalam laporan tahunan

Kepemilikan Institusional

$\mathrm{KI}_{i t}=\frac{\text { Jumlah kepemilikan saham oleh investor institus } i}{\text { Total jumlah saham yang beredar. }}$

Liputan Media Liputan media merupakan pemberitaan-pemberitaan mengenai tanggung jawab perusahaan terhadap lingkungan. Pengukuran media dalam penelitian ini adalah media umum dan media lingkungan. Media umum terdiri atas Tribunnews, Republika, Bisnis, CNN, Okezone, Beritasatu, SINDONEWS, Merdeka, Kompas, Antara News, Kontan, Tempo, SWA, IICG, Detik. Sedangkan, media lingkungan terdiri atas Mongabay, WALHI, Greenpeace Indonesia, website perusahaan. Perhitungan variabel liputan media merujuk pada penelitian Janis dan Fadner (1995); Bansal dan Clelland (2004) dalam Rupley et al., (2012) dengan rumus sebagai berikut:

$* \frac{e^{2}}{2}$ if $\mathrm{e}>\mathrm{C}$

$* * \frac{e c-c^{2}}{t}$ if $\mathrm{c}>\mathrm{e}$

$* * * 0$ if $\mathrm{e}=\mathrm{c}$

Keterangan:

e : Menggambarkan jumlah artikel lingkungan yang positif.

c : Jumlah artikel lingkungan yang negatif. $t$ adalah sama dengan $e+c$.

* : Jika artikel positif lebih banyak dari artikel negatif maka menggunakan rumus pertama.

** : Jika artikel negatif lebih banyak dari artikel positif maka menggunakan rumus kedua.

*** : Jika artikel bersifat netral, tidak ada pengungkapan atau jumlah antara artikel positif dan negatif sama maka langsung dihitung dengan nominal 0. 


\section{Variabel Kontrol}

Ukuran Perusahaan

FIRM_SIZE $i t=$ Log Natural dari Total Penjualan

Profitabilitas

$\mathrm{ROA}_{i t}=\frac{\text { Laba Bersih }}{\text { Total Aset }}$

\section{Metode Analisis Data}

\section{Uji Principal Component Analysis (PCA)}

Uji Principal Component Analysis (PCA) dilakukan untuk menyederhanakan dari variabel struktur tata kelola perusahaan. Uji yang digunakan dalam principal component analysis antara lain uji determinant of correlation matrix, uji Kaiser Meyer Olkin (KMO), melihat nilai Measure of Sampling Adequacy (MSA) harus di atas 0,5, dan uji komunalitas dengan menggunakan SPSS 20.

\section{Regresi Data Panel}

Pada regresi data panel dilakukan analisis statistik deskriptif, estimasi model regresi data panel, dan pemilihan teknik estimasi regresi data panel menggunakan software Eviews 10. Uji statistik deskriptif digunakan untuk melihat nilai terendah, nilai tertinggi, nilai rata-rata dan simpangan baku dari masing-masing variabel. Selanjutnya dilakukan estimasi model regresi data panel yang terdiri dari Common Effect Model, Fixed Effect Model, dan Random Effect Model. Model-model regresi data panel yang diperoleh menjadi dasar pemilihan atas model regresi terbaik. Proses pemilihan menggunakan uji Chow, uji Lagrange Multiplier (LM) dan uji Hausman. Uji asumsi klasik tidak diperlukan dalam analisis data panel karena data panel dapat mengurangi bias yang kemungkinan besar muncul dalam hasil analisis, memberi lebih banyak informasi, variasi, dan degree of freedom (Gujarati, 2012). Model regresi data panel yang digunakan adalah sebagai berikut.

DQ_QUALITY $i t=\alpha+\beta_{1}$ LINGKUNGAN $_{i t}+\beta_{2}$ SEN_IND $_{i t}+\beta_{3} G_{\text {GCG }}+\beta_{4}$ MEDIA $_{i t}+\beta_{5}$ FIRM_SIZE $_{i t}+\beta_{6}$ ROA $_{i t}+\varepsilon$

\section{Keterangan:}

DQ_QUALITYit: Kualitas pengungkapan lingkungan yang merupakan total skor indicator environmental disclosure (compliance, stewardship, dan sustainable development)
A
: Konstanta
$\beta 1-\beta 6$
: Koefisien Regresi 


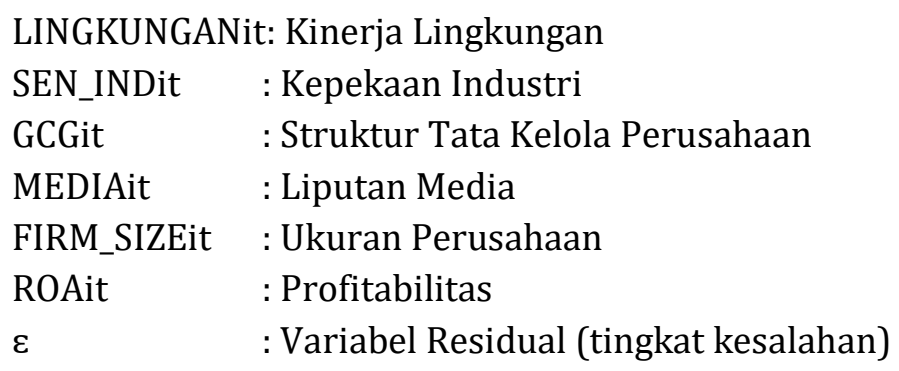

\section{Regresi Linear Berganda}

Pada regresi linear berganda dilakukan analisis statistik deskriptif, uji asumsi klasik, uji Goodness of Fit (Uji F), koefisien determinasi (R2), dan uji statistik dengan menggunakan software Eviews 10. Analisis statistik deskriptif digunakan untuk melihat nilai terendah, nilai tertinggi, nilai ratarata dan simpangan baku dari masing-masing variabel. Uji asumsi klasik terdiri dari Uji Goodness of Fit (Uji F) untuk melihat kelayakan model regresi. Koefisien determinasi (R2) untuk mengetahui seberapa besar kemampuan model dalam menjelaskan variabel dependen. Uji statistik untuk mengetahui pengaruh variabel independen terhadap variabel dependen. Model regresi linear berganda yang digunakan adalah sebagai berikut.

TOBINS_Q $=\alpha+\beta 1$ DQ_QUALITY $+\beta 2$ FIRM_SIZE $+\beta 3$ ROA $+\varepsilon$

Keterangan:

TOBINS_Q : Nilai Perusahaan

$\alpha: \quad$ : Konstanta

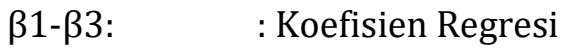

DQ_QUALITY : Kualitas pengungkapan lingkungan yang merupakan total skor indikator environmental disclosure (compliance, pollution prevention, product stewardship, dan sustainable development)

FIRM_SIZE : Ukuran Perusahaan

ROA : Profitabilitas

$\varepsilon \quad$ : Variabel residual (tingkat kesalahan)

\section{Hasil dan Pembahasan}

\section{Hasil}

\section{Hasil Uji Principal Component Analysis (PCA)}

Pengujian Principal Component Analysis (PCA) untuk faktor struktur tata kelola perusahaan dilakukan dengan menggunakan tujuh variabel yaitu komisaris independen, keberagaman gender, multiple directorship, ukuran dewan komisaris, kepemilikan manajerial, komite audit, dan kepemilikan institusional. 
Hasil pengujian PCA pertama menunjukkan variabel keberagaman gender tidak memenuhi syarat nilai Measure of Sampling Adequacy (MSA). Oleh karenanya, dilakukan pengujian ulang tanpa mengikutsertakan variabel keragaman gender. Hasil pengujian PCA kedua menunjukkan variabel komisaris independen tidak memenuhi syarat nilai MSA.

Oleh karenanya, dilakukan pengujian ulang tanpa mengikutsertakan variabel komisaris independen. Hasil pengujian PCA ketiga menunjukkan variabel kepemilikan manajerial tidak memenuhi syarat nilai MSA. Kemudian pengujian ulang dilakukan tanpa mengikutsertakan variabel kepemilikan manajerial. Hasil pengujian PCA keempat menunjukkan variabel multiple directorship tidak memenuhi uji komunalitas. Hasil pengujian PCA kelima terdapat tiga variabel yang telah lolos uji yaitu ukuran dewan komisaris, komite audit, dan kepemilikan institusional.

\section{Tabel 1. Matrik Korelasi}

\begin{tabular}{ccccc}
\hline & & BS & KAI & KI \\
\hline \multirow{3}{*}{ Correlation } & BS & 1,000 & 0,464 & 0,287 \\
& KAI & 0,464 & 1,000 & 0,413 \\
& KI & 0,287 & 0,413 & 1,000 \\
Sig. (1-tailed) & BS & & 0,000 & 0,001 \\
& KAI & 0,000 & & 0,000 \\
\cline { 3 - 5 } & KI & 0,001 & 0,000 & \\
\hline
\end{tabular}

a. Determinant $\mathbf{= 0 , 6 4 1}$

Sumber: Data Diolah (2019)

Tabel 1 menunjukkan nilai Determinant of Correlation Matrix sebesar 0,641 mendekati nilai 0 . Hal ini menunjukkan matrik korelasi antara variabel saling terkait.

\section{Tabel 2. KMO dan Bartlett Test of Sphericity}

\begin{tabular}{|c|c|c|}
\hline \multicolumn{2}{|c|}{ Kaiser-Meyer-Olkin Measure of Sampling Adequacy } & 0,626 \\
\hline & Approx. Chi-Square & 46,724 \\
\hline \multirow{2}{*}{$\begin{array}{l}\text { Bartlett's Test of } \\
\text { Sphericity }\end{array}$} & Df & 3 \\
\hline & Sig. & 0,000 \\
\hline
\end{tabular}

Sumber: Data Diolah (2019)

Hasil uji pada Tabel 2 menunjukkan nilai Kaiser Meyer Olkin (KMO) sebesar 0,626. Oleh karenanya, persyaratan Kaiser Meyer Olkin (KMO) telah terpenuhi karena memiliki nilai KMO > 0,5.

Tabel 3. Anti Image Matrices

\begin{tabular}{lcccc}
\hline & & BS & KAI & KI \\
\hline \multirow{2}{*}{ Anti-image Covariance } & BS & 0,773 & $-0,291$ & $-0,094$ \\
& KAI & $-0,291$ & 0,699 & $-0,249$ \\
\hline
\end{tabular}




\begin{tabular}{ccccc}
\hline & & BS & KAI & KI \\
\hline \multirow{3}{*}{ Anti-image Correlation } & KI & $-0,094$ & $-0,249$ & 0,818 \\
\hline & KS & $0,635^{\text {a }}$ & $-0,396$ & $-0,118$ \\
& KI & $-0,396$ & $0,592^{\text {a }}$ & $-0,330$ \\
& $-0,118$ & $-0,330$ & $0,673^{\text {a }}$ \\
\hline
\end{tabular}

a. Measures of Sampling Adequacy(MSA)

Sumber: Data Diolah (2019)

Pada Tabel 3 di atas menunjukkan nilai MSA variabel BS sebesar 0,635, nilai MSA variabel KAI sebesar 0,592, nilai MSA variabel KI sebesar 0,673. Dari ketiga variabel yang diuji memenuhi persyaratan MSA yaitu di atas 0,5. Oleh karenanya, dilakukan pengujian selanjutnya yaitu komunalitas.

Tabel 4. Komunalitas

\begin{tabular}{ccc}
\hline & Initial & Extraction \\
\hline BS & 1,000 & 0,575 \\
KAI & 1,000 & 0,690 \\
KI & 1,000 & 0,516 \\
\hline
\end{tabular}

Sumber: Data Diolah (2019)

Tabel 4 di atas menunjukkan tiga variabel yang memenuhi persyaratan komunalitas yaitu >0,5. Uji komunalitas menunjukkan seberapa besar variabel dalam menjelaskan faktor. Variabel BS bernilai 0,575, artinya variabel BS dapat menjelaskan faktor tata kelola perusahaan sebesar 57,5\%. Variabel KAI bernilai 0,690 artinya variabel KAI dapat menjelaskan faktor tata kelola perusahaan sebesar $69 \%$. Sedangkan variabel KI bernilai 0,516 artinya variabel KI dapat menjelaskan faktor tata kelola perusahaan sebesar $51,6 \%$.

Lebih lanjut pada Tabel 5 component matrix menunjukkan seberapa kemampuan variabel berkorelasi dengan faktor yang telah terbentuk. BS berkorelasi 0,758 dengan faktor 1 dan KAI berkorelasi sebesar 0,831 dengan faktor 1. Sedangkan KI berkorelasi 0,718 dengan faktor 1 . Kemudian, dilanjutkan dengan penentuan faktor skor untuk regresi.

Tabel 5. Component Matrix

\begin{tabular}{cc}
\hline & Component \\
& 1 \\
\hline BS & 0,758 \\
KAI & 0,831 \\
KI & 0,718 \\
\hline
\end{tabular}

Sumber: Data Diolah (2019) 


\section{Hasil Regresi Data Panel}

\section{Hasil Analisis Statistik Deskriptif}

Hasil analisis statistik deskriptif, variabel kualitas pengungkapan lingkungan memunyai nilai terendah sebesar 3. Nilai terendah dimiliki oleh PT Mayora Indah Tbk pada tahun 2015. Nilai tertinggi sebesar 135 dimiliki oleh PT Aneka Tambang Tbk pada tahun 2016. Variabel kinerja lingkungan memunyai nilai terendah sebesar 2. Nilai terendah dimiliki oleh PT Akasha Wira International Tbk pada tahun 2016, PT Martina Berto Tbk pada tahun 2016 dan 2017, PT Mustika Ratu Tbk pada tahun 2017, dan PT Mayora Indah Tbk pada tahun 2015, sebagaimana pada Tabel 6.

Tabel 6. Hasil Statistik Deskriptif

\begin{tabular}{cccccc}
\hline & N & $\begin{array}{c}\text { Nilai } \\
\text { Terendah }\end{array}$ & $\begin{array}{c}\text { Nilai } \\
\text { Tertinggi }\end{array}$ & $\begin{array}{c}\text { Nilai Rata- } \\
\text { Rata }\end{array}$ & $\begin{array}{c}\text { Simpangan } \\
\text { Baku }\end{array}$ \\
\hline DQ_QUALITY & 108 & 3,000000 & 135,0000 & 51,95370 & 37,62465 \\
LINGKUNGAN & 108 & 2,000000 & 5,000000 & 3,212963 & 0,596735 \\
SEND_IND & 108 & 0,000000 & 1,000000 & 0,388889 & 0,489771 \\
GCG & 108 & $-2,648760$ & 2,408710 & 0,010455 & 0,999888 \\
MEDIA & 108 & $-0,120000$ & 0,808889 & 0,260656 & 0,295070 \\
FIRM_SIZE & 108 & 26,18151 & 31,88218 & 29,43052 & 1,398169 \\
ROA & 108 & $-0,644139$ & 0,965469 & 0,082201 & 0,157706 \\
\hline
\end{tabular}

Sumber: Data Diolah (2019)

Nilai tertinggi sebesar 5 dimiliki oleh PT Bukit Asam (Persero) Tbk pada tahun 2015 dan 2016, PT Medco Energi Internasional Tbk pada tahun 2015, 2016, dan 2017. Variabel struktur tata kelola perusahaan memunyai nilai terendah sebesar -2,648760. Nilai terendah dimiliki oleh PT Borneo Lumbung Energi dan Metal Tbk pada tahun 2016 dan 2017. Nilai tertinggi sebesar 2,408710 dimiliki oleh PT Perusahaan Gas Negara (Persero) Tbk pada tahun 2015. Kemudian, variabel liputan media mempunyai nilai terendah sebesar $-0,12$. Nilai terendah dimiliki oleh PT Bumi Resources Tbk pada tahun 2015. Nilai tertinggi sebesar 0,808889 dimiliki oleh PT Aneka Tambang Tbk pada tahun 2016

Hasil Pemilihan Teknik Estimasi Regresi Data Panel

Dalam estimasi model regresi data panel ada tiga model yang digunakan yaitu common effect model, fixed effect model, dan random effect model. Sedangkan teknik estimasi untuk memilih regresi data panel yaitu uji chow (uji statistik F), uji lagrange multiplier, dan uji hausman. Pengujian teknik estimasi uji chow tidak dilakukan dikarenakan fixed effect model tidak muncul dikarenakan terdapat variabel dummy yaitu kepekaan industri. Oleh karenanya, hanya muncul "error message: near singular matrix" pada software Eviews 10. Setelah itu dicoba pengujian regresi data panel model fixed effect menggunakan software SPSS. 
Hasil menunjukkan variabel kepekaan industri dikeluarkan dalam model regresi. Hal ini dapat diketahui dari tabel excluded variabel berikut ini.

\section{Tabel 7. Excluded Variables}

\begin{tabular}{|c|c|c|c|c|c|c|c|}
\hline \multirow[b]{2}{*}{ Model } & \multirow[b]{2}{*}{ Beta In } & \multirow[b]{2}{*}{$\mathrm{t}$} & \multirow[b]{2}{*}{ Sig. } & \multirow{2}{*}{$\begin{array}{c}\text { Partial } \\
\text { Correlation }\end{array}$} & \multicolumn{3}{|c|}{ Collinearity Statistics } \\
\hline & & & & & Tolerance & VIF & $\begin{array}{l}\text { Minimum } \\
\text { Tolerance }\end{array}$ \\
\hline 1 &.$b$ & . & & . & 0,000 & & 0,000 \\
\hline
\end{tabular}

Sumber: Data Diolah (2019)

Berdasarkan Tabel 7, terlihat bahwa variabel SEND_IND dikeluarkan dalam model regresi. Sedangkan variabel kepekaan industri merupakan variabel yang penting yaitu variabel independen dalam penelitian ini. Oleh karenanya uji chow tidak dilakukan dan langsung menggunakan uji Lagrange Multiplier (LM) untuk mengetahui apakah model random effect lebih baik dari pada model common effect (OLS).

\section{Tabel 8. Hasil Uji Lagrange Multiplier (LM)}

\begin{tabular}{cccc}
\hline $\begin{array}{c}\text { Null (no rand. effect) } \\
\text { Alternative }\end{array}$ & $\begin{array}{c}\text { Cross-section One- } \\
\text { sided }\end{array}$ & $\begin{array}{c}\text { Period One- } \\
\text { sided }\end{array}$ & Both \\
\hline Breusch-Pagan & 29,62771 & 1,279029 & 30,90674 \\
& $(0,0000)$ & $(0,2581)$ & $(0,0000)$ \\
\hline
\end{tabular}

Sumber: Data Diolah (2019)

Tabel 8 menunjukkan nilai probabilitas Breusch-Pagan sebesar $0.0000<0,05$, maka estimasi yang tepat untuk model regresi data panel adalah random effect.

Hasil Uji Goodness of Fit (Uji F) dan Koefisien Determinasi ( ${ }^{2}$ )

Berdasarkan Tabel 9 diperoleh probabilitas (F-statistic) sebesar 0,000000. Oleh karena nilai probabilitas (F-statistic) $<0,05$, maka dapat disimpulkan model regresi layak. Nilai Adjusted $\mathrm{R}^{2}$ adalah sebesar 0,510133, hal ini menunjukkan 51,0133\% kualitas pengungkapan lingkungan dapat dijelaskan oleh variasi dari empat variabel independen yaitu kinerja lingkungan, kepekaan industri, struktur tata kelola perusahaan, dan liputan media, serta variabel kontrol yaitu ukuran perusahaan dan profitabilitas.

Sedangkan sisanya 48,9867\% dijelaskan oleh sebab-sebab lain di luar model. Berdasarkan hasil uji asumsi klasik yang telah dilakukan model regresi memenuhi persyaratan data normalitas, dan tidak ada multikolinearitas, heteroskedastisitas maupun autokorelasi. 
Tabel 9. Hasil Uji Regresi Data Panel Random Effect Model

\begin{tabular}{ccccc}
\hline Variable & Coefficient & Std. Error & t-Statistic & Prob. \\
\hline C & $-92,56238$ & 59,26204 & $-1,561917$ & 0,1214 \\
LINGKUNGAN & 10,43538 & 3,316515 & 3,146488 & 0,0022 \\
SEND_IND & 14,99955 & 5,700050 & 2,631477 & 0,0098 \\
GCG & 10,48404 & 2,712340 & 3,865311 & 0,0002 \\
MEDIA & 31,50985 & 7,555907 & 4,170227 & 0,0001 \\
FIRM_SIZE & 3,204199 & 2,046741 & 1,565513 & 0,1206 \\
ROA & 30,78283 & 8,740173 & 3,521993 & 0,0006 \\
\hline R-squared & 0,537602 & Mean dependent var & & 19,52467 \\
Adjusted R-squared & 0,510133 & S.D. dependent var & & 16,66919 \\
S.E. of regression & 11,66685 & Sum squared resid & & 13747,65 \\
F-statistic & 19,57111 & Durbin-Watson stat & & 1,626063 \\
Prob(F-statistic) & 0,000000 & & & \\
\hline Sumber: Data Diolah $(2019)$ & & &
\end{tabular}

\section{Pembahasan}

\section{Pengaruh Kinerja Lingkungan terhadap Kualitas Pengungkapan Lingkungan}

Hasil uji hipotesis menunjukkan variabel kinerja lingkungan berpengaruh positif signifikan terhadap kualitas pengungkapan lingkungan dengan tingkat signifikansi 5\% $\left(0,0022<0,05, \mathrm{H}_{1}\right.$ diterima $)$. Berdasarkan hasil tersebut, dapat dikatakan perusahaan yang memunyai kinerja lingkungan baik akan memunyai pengungkapan lingkungan yang semakin berkualitas. Hal tersebut dilakukan sebagai upaya dalam membedakan diri dari perusahaan yang memiliki kinerja lingkungan yang buruk. Pelaku lingkungan yang baik percaya bahwa dengan mengungkapkan kinerja lingkungan mereka akan memberikan keuntungan bagi perusahaan (Aulia dan Agustina, 2015).

Hasil penelitian ini sejalan dengan penelitian yang dilakukan Aulia dan Agustina (2015) yang menunjukkan hasil kinerja lingkungan berpengaruh terhadap environmental disclosure. Sejalan pula dengan hasil penelitian Wulandari dan Puspaningsih (2017) yang menunjukkan kinerja lingkungan secara positif berpengaruh terhadap corporate social responsibility. Namun, tidak sejalan dengan hasil penelitian Sukasih dan Sugiyanto (2017) yang menunjukkan hasil kinerja lingkungan yang diukur dengan peringkat PROPER tidak berpengaruh signifikan terhadap corporate social responsibility.

\section{Pengaruh Kepekaan Industri terhadap Kualitas Pengungkapan Lingkungan}

Hasil uji hipotesis menunjukkan bahwa kepekaan industri berpengaruh positif signifikan terhadap kualitas pengungkapan lingkungan dengan tingkat 
signifikansi 5\% (0,0098< 0,05, H2 diterima). Berdasarkan hasil tersebut, dapat dikatakan perusahaan yang memiliki kepekaan lingkungan yang lebih besar yaitu perusahaan pertambangan akan melakukan pengungkapan lingkungan yang berkualitas dari pada perusahaan industri lainnya. Hal ini dikarenakan perusahaan tambang merupakan perusahaan yang mendapat sorotan dari masyarakat karena aktivitas operasionalnya yang berpotensi merusak alam. Akibat dampak aktivitas operasional yang ditimbulkan oleh perusahaan tambang, perusahaan tambang semakin dituntut masyarakat dalam melakukan pertanggungjawaban pada lingkungan.

Temuan ini mengonfirmasi teori legitimasi bahwa perusahaan yang memiliki kepekaan lingkungan yang tinggi akan mengungkapkan aktifitas lingkungannya semakin baik untuk mendapatkan legitimasi agar mendapatkan legitimasi dari para stakeholder dan keberlangsungan usahanya. Hasil penelitian ini sejalan dengan penelitian yang dilakukan Rupley, et al., (2012) dan Solikhah dan Winarsih (2016) yang menunjukkan variabel kepekaan industri berpengaruh signifikan terhadap kualitas pengungkapan lingkungan.

\section{Pengaruh Struktur Tata Kelola Perusahaan terhadap Kualitas Pengungkapan Lingkungan}

Hasil uji hipotesis menunjukkan struktur tata kelola perusahaan berpengaruh positif signifikan terhadap kualitas pengungkapan lingkungan (dengan tingkat signifikansi 5\% (0,0002 < 0,05, H3 diterima). Variabel struktur tata kelola perusahaan merupakan hasil dari penyederhanaan menggunakan Principal Component Analysis (PCA) yang menghasilkan tiga variabel yang berpengaruh terhadap kualitas pengungkapan lingkungan yaitu ukuran dewan komisaris, komite audit, dan kepemilikan institusional. Hasil penelitian ini mengonfirmasi teori agensi bahwa struktur tata kelola perusahaan merupakan mekanisme pengelolaan perusahaan yang baik. Semakin banyak dewan komisaris dalam perusahaan, maka pengungkapan lingkungan akan berkualitas dikarenakan terdapat sistem pemantauan yang semakin baik dari perusahaan.

Sedangkan, komite audit terlibat dalam proses pelaporan keuangan, sehingga komite audit berkontribusi dalam pelaporan lingkungan. Oleh karenanya, semakin banyak komite audit maka semakin berkualitas pengungkapan lingkungan bagi stakeholders. Kepemilikian institusional juga dapat meningkatkan kualitas pengungkapan lingkungan karena investor institusional memunyai lebih banyak pengalaman dalam menerapkan prinsip corporate governance yang baik untuk melindungi hakhak pemegang saham (Murwaningsari, 2009). Hak-hak tersebut termasuk informasi mengenai pengungkapan lingkungan perusahaan. 
Hasil penelitian ini sejalan dengan hasil penelitian yang dilakukan Solikhah dan Winarsih (2016), menunjukkan ukuran dewan komisaris berpengaruh terhadap kualitas pengungkapan lingkungan. Sejalan pula dengan hasil penelitian Laksmi dan Kamila (2018) yang menunjukkan variabel komite audit yang diukur dengan jumlah anggota komite audit memiliki dampak positif yang signifikan terhadap pengungkapan tanggung jawab sosial perusahaan. Demikian pula dengan hasil penelitian Sari, et al., (2013) yang menunjukkan kepemilikan institusional berpengaruh terhadap Corporate Social Responsibility.

\section{Pengaruh Liputan Media terhadap Kualitas Pengungkapan Lingkungan}

Hasil uji hipotesis menunjukkan bahwa liputan media berpengaruh positif signifikan terhadap kualitas pengungkapan lingkungan dengan tingkat signifikansi 5\% (0,0001<0,05, H4 diterima). Berdasarkan hasil tersebut, dapat dikatakan bahwa pemberitaan perusahaan mengenai aktifitas lingkungan akan meningkatkan juga kualitas pengungkapan lingkungan perusahaan. Media akan menciptakan kesadaran pemangku kepentingan tentang masalah lingkungan perusahaan sehingga manajemen perusahaan merespon dengan menyediakan environmental disclosure (Rupley, et al., 2012).

Hasil penelitian ini sejalan dengan hasil penelitian Rupley, et al., (2012) dan Aulia dan Agustina (2015) menunjukkan bahwa variabel liputan media berpengaruh signifikan terhadap environmental disclosure. Namun, penelitian ini menunjukkan hasil yang berbeda dengan hasil penelitian Hadjoh dan Sukartha (2013) dan Solikhah dan Winarsih (2016) yang menunjukkan eksposur media tidak berpengaruh pada pengungkapan lingkungan.

\section{Hasil Regresi Linear Berganda}

\section{Hasil Analisis Statistik Deskriptif}

Berdasarkan hasil statistik deskriptif, Tabel 10, variabel nilai perusahaan memunyai nilai terendah sebesar 0,388070. Nilai terendah dimiliki oleh PT Surya Esa Perkasa Tbk pada tahun 2015. Nilai tertinggi sebesar 18,64041 dimiliki oleh PT Unilever Indonesia Tbk pada tahun 2015. Variabel kualitas pengungkapan lingkungan memunyai nilai terendah sebesar 3. Nilai terendah dimiliki oleh PT Mayora Indah Tbk pada tahun 2015. Nilai tertinggi sebesar 135 dimiliki oleh PT Aneka Tambang Tbk pada tahun 2016.

Tabel 10. Hasil Statistik Deskriptif

\begin{tabular}{cccccc}
\hline & $\mathrm{N}$ & $\begin{array}{c}\text { Nilai } \\
\text { Terendah }\end{array}$ & $\begin{array}{c}\text { Nilai } \\
\text { Tertinggi }\end{array}$ & $\begin{array}{c}\text { Nilai } \\
\text { Rata-Rata }\end{array}$ & $\begin{array}{c}\text { Simpangan } \\
\text { Baku }\end{array}$ \\
\hline TOBINS_Q & 108 & 0,388070 & 18,64041 & 2,193280 & 3,256827 \\
\hline
\end{tabular}




\begin{tabular}{lccccc}
\hline & N & $\begin{array}{c}\text { Nilai } \\
\text { Terendah }\end{array}$ & $\begin{array}{c}\text { Nilai } \\
\text { Tertinggi }\end{array}$ & $\begin{array}{c}\text { Nilai } \\
\text { Rata-Rata }\end{array}$ & $\begin{array}{c}\text { Simpangan } \\
\text { Baku }\end{array}$ \\
\hline DQ_QUALITY & 108 & 3,000000 & 135,0000 & 51,95370 & 37,62465 \\
FIRM_SIZE & 108 & 26,18151 & 31,88218 & 29,43052 & 1,398169 \\
ROA & 108 & $-0,644139$ & 0,965469 & 0,082201 & 0,157706 \\
\hline
\end{tabular}

Sumber: Data Diolah (2019)

\section{Hasil Uji Regresi Linear Berganda}

Tabel 11 menunjukkan hasil uji Goodness of Fit dan koefisien determinasi. Pengujian ini dilakukan dengan menggunakan tingkat signifikan $5 \%$. Berdasarkan Tabel 11 diperoleh probabilitas (F-statistic) yaitu 0,00. Oleh karena nilai probabilitas (F-statistic) $<0,05$, maka model regresi dalam penelitian ini layak. Kemudian, koefisien determinasi berguna untuk mengetahui kemampuan variabel independen dalam menjelaskan variabel dependen. Hasil juga menunjukkan bahwa nilai Adjusted $\mathrm{R}^{2}$ adalah sebesar 0,251774 , hal ini menunjukkan $25,1774 \%$ nilai perusahaan dapat dijelaskan oleh variasi dari variabel independen kualitas pengungkapan lingkungan dan variabel kontrol ukuran perusahaan dan profitabilitas. Sedangkan sisanya $74,8226 \%$ dijelaskan oleh sebab-sebab lain di luar model.

\section{Tabel 11. Hasil Uji Regresi Linear Berganda}

\begin{tabular}{ccccc}
\hline Variabel & Coefficient & Std. Error & t-Statistic & Prob. \\
C & 0.011255 & 0.068309 & 0.164760 & 0.8695 \\
DQ_QUALITY & 0.411219 & 0.165713 & 2.481519 & 0.0147 \\
FIRM_SIZE & 0.021562 & 0.084615 & 0.254822 & 0.7994 \\
ROA & 0.953332 & 0.433808 & 2.197592 & 0.0302 \\
\hline R-squared & 0.272951 & Mean dependent var & 0.022897 \\
Adjusted R-squared & 0.251774 & S.D. dependent var & 0.810206 \\
\hline S.E. of regression & 0.700829 & Akaike info criterion & 2.163560 \\
Sum squared resid & 50.58958 & Schwarz criterion & 2.263479 \\
Log likelihood & -111.7505 & Hannan-Quinn & 2.204066 \\
& & criter. & \\
F-statistic & 12.88951 & Durbin-Watson stat & \\
Prob(F-statistic) & 0.000000 & Wald F-statistic & \\
Prob(Wald F- & 0.009373 & & & \\
statistic) & & & \\
\hline
\end{tabular}

Sumber: Data Diolah (2019)

\section{Pengaruh Kualitas Pengungkapan Lingkungan terhadap Nilai Perusahaan}

Hasil uji hipotesis menunjukkan bahwa kualitas pengungkapan lingkungan berpengaruh positif terhadap nilai perusahaan dengan tingkat signifikansi 5\% $\left(0,0147<0,05, \mathrm{H}_{5}\right.$ diterima $)$. Berdasarkan hasil tersebut, dapat dikatakan bahwa perusahaan yang mengungkapkan aktifitas tanggung jawab lingkungan 
secara berkualitas akan memiliki nilai perusahaan yang semakin baik. Hal ini dikarenakan investor tidak hanya melihat aspek keuangan saja dari perusahaan namun juga memperhatikan aspek tanggung jawab lingkungan perusahaan sebagai pertimbangan dalam berinvestasi. Hasil penelitian ini mengkonfirmasi teori legitimasi bahwa perusahaan untuk dapat diterima masyarakat harus menyelaraskan antara tujuan ekonomi dengan tujuan lingkungan dan sosialnya. Hasil penelitian ini sejalan dengan penelitian Radhouane, et al., (2018) yang menunjukkan hasil pengungkapan lingkungan berpengaruh positif signifikan terhadap nilai perusahaan. Namun, tidak sejalan dengan hasil penelitian Deswanto dan Siregar (2018) menunjukkan hasil pengungkapan lingkungan tidak berpengaruh terhadap nilai perusahaan.

\section{Simpulan}

Penelitian ini bertujuan untuk menguji pengaruh kinerja lingkungan, kepekaan industri, struktur tata kelola perusahaan, dan liputan media terhadap kualitas pengungkapan lingkungan. Serta, menguji kualitas pengungkapan lingkungan terhadap nilai perusahaan. Berdasarkan hasil penelitian, kinerja lingkungan, kepekaan industri, struktur tata kelola perusahaan, dan liputan media berpengaruh positif terhadap kualitas pengungkapan lingkungan. Pengujian kualitas pengungkapan lingkungan terhadap nilai perusahaan menunjukkan hasil kualitas pengungkapan lingkungan berpengaruh positif terhadap nilai perusahaan.

Hasil penelitian ini mengkonfirmasi teori agensi bahwa perbedaan kepentingan prinsipal dan agen memunculkan kewajiban perusahaan untuk memiliki struktur tata kelola perusahaan untuk pengungkapan lingkungan yang berkualitas. Variabel dari struktur tata kelola perusahaan merupakan hasil dari pengujian principal component analysis yang menghasilkan satu komponen, yang terdiri atas ukuran dewan komisaris, komite audit, dan kepemilikan institusional yang berpengaruh terhadap kualitas pengungkapan lingkungan.

Asumsi teori agensi menjelaskan ukuran dewan komisaris yang semakin besar maka pengawasan akan semakin baik. Oleh karenanya, informasi mengenai pengungkapan lingkungan akan diungkapkan secara lebih berkualitas. Keberadaan komite audit membantu memastikan informasi yang diberikan manajer kepada pihak shareholder telah bebas dari informasi yang menyesatkan termasuk informasi mengenai pengungkapan lingkungan. Kepemilikan institusional juga memiliki peran dalam mengurangi agency problem dalam perusahaan. Semakin besar dari kepemilikan institusional maka hak-hak dari pemegang saham akan semakin terlindungi. Hal ini dikarenakan terdapat monitoring yang lebih besar dari pihak eksternal perusahaan yaitu investor institusional. 
Hasil penelitian ini mengkonfirmasi teori legitimasi bahwa apabila perusahaan ingin tetap sustain maka perusahaan harus menyelaraskan tujuan ekonomi dengan tujuan sosial dan lingkungan. Perusahaan yang memiliki kinerja lingkungan dan liputan media yang baik merupakan bentuk penyelarasan kepentingan ekonomi dengan tujuan lingkungan. Hal ini dikarenakan perusahaan yang memiliki kinerja lingkungan dan liputan media yang baik telah melakukan tanggung jawab lingkungan secara berkualitas. Perusahaan yang memiliki kepekaan lingkungan yang besar akan mengungkapkan aktifitas lingkungannya semakin baik untuk mendapatkan legitimasi dari para stakeholder dan keberlangsungan usahanya. Aktivitas tanggung jawab lingkungan yang dimiliki oleh perusahaan akan diungkapkan dalam pengungkapan lingkungan yang berkualitas untuk mendapatkan legitimasi.

Pada praktiknya, perusahaan harus mempunyai kinerja lingkungan, struktur tata kelola perusahaan, dan liputan media yang baik untuk dapat mengungkapan tanggung jawab lingkungan secara berkualitas. Kinerja lingkungan yang baik dapat dimiliki oleh perusahaan dengan memenuhi ketaatan persyaratan dokumen lingkungan dan pelaporannya, pengendalian pencemaran air, pengendalian pencemaran udara, pengelolaan limbah B3 dan potensi kerusakan lahan. Perusahaan yang memiliki kepekaan yang lebih tinggi terhadap lingkungan yaitu pertambangan akan lebih disorot oleh masyarakat dalam aktifitas operasionalnya. Oleh karena itu, perusahaan pertambangan lebih banyak melaporkan tanggung jawab lingkungannya dalam pengungkapan lingkungan demi keberlangsungan perusahaan.

Struktur tata kelola perusahaan yang baik juga diperlukan bagi perusahaan terutama pada ukuran dewan komisaris, komite audit dan kepemilikan institusional dalam pengungkapan lingkungan yang berkualitas. Pemberitaan perusahaan mengenai aktifitas lingkungan juga meningkatkan kualitas pengungkapan lingkungan perusahaan. Media akan menciptakan kesadaran pemangku kepentingan tentang masalah lingkungan perusahaan sehingga manajemen perusahaan merespon dengan menyediakan environmental disclosure. Perusahaan diharapkan memiliki pengungkapan lingkungan yang berkualitas. Hal ini dikarenakan hasil pada penelitian ini menunjukkan perusahaan yang memiliki pengungkapan lingkungan yang berkualitas memiliki nilai perusahaan yang meningkat pula.

Penelitian ini tidak terlepas dari keterbatasan, salah satunya adalah keterbatasan dalam metode regresi data panel. Pada regresi data panel hasil model fixed effect mengeluarkan variabel kepekaan industri dalam model regresi. Sehingga, tidak dapat dilakukan uji chow dan hausman untuk pengujian model terbaik. Selain itu, perusahaan perhutanan sebagai salah satu sampel dalam penelitian ini tidak ada yang listing di Bursa Efek Indonesia. Dengan 
demikian, penelitian ini tidak memasukkan perusahaan perhutanan. Saran bagi perusahaan yaitu perusahaan perlu melaksanakan pengungkapan lingkungan yang berkualitas dikarenakan hasil penelitian menunjukkan bahwa pengungkapan lingkungan berkualitas dapat menjadi solusi dalam mereduksi asimetri informasi dan pada akhirnya meningkatkan nilai perusahaan. Kemudian saran bagi penelitian selanjutnya untuk menambahkan sampel di berbagai sektor industri seperti rokok dan sawit, sehingga dapat digeneralisir pada semua sektor.

\section{Daftar Pustaka}

Anggraeni, D. Y., dan C. D. Djakman. 2017. Slack Resources, Feminisme Dewan, dan Kualitas Pengungkapan Tanggung Jawab Sosial Perusahaan (Slack Resources, Board's Feminism, and the Quality of Corporate Social Responsibility Disclosure). Jurnal Akuntansi dan Keuangan Indonesia 14 (1): 94-118.

Aulia, F. Z., dan L. Agustina. 2015. Pengaruh Karakteristik Perusahaan, Kinerja Lingkungan dan Liputan Media Terhadap Environmental Disclosure. Accounting Analysis Journal 4 (3): 1-8.

Badan Nasional Penanggulangan Bencana (BNPB). 2018. Tren Kejadian Bencana 4 Tahun Terkahir. [Online] Available at: https://dibi.bnpb.cloud/

Barnhart, S. W., dan S. Rosenstein. 1998. Board Composition, Managerial Ownership, and Firm Performance: An Empirical Analysis. Journal of Accounting Research Fall 33 (4): 1-16.

Deswanto, R. B., dan S. V. Siregar. 2018. The Associations Between Environmental Disclosures with Financial Performance, Environmental Performance, and Firm Value. Social Responsibility Journal 14 (1): 180193.

Forum For Corporate Governance In Indonesia. 2001. Peranan Dewan Komisaris dan Komite Audit dalam Pelaksanaan Corporate Governance (Tata Kelola Perusahaan). Jakarta. Gujarati, D. 2012. Dasar-Dasar Ekonometrika. Jakarta: Salemba Empat.

Hadjoh, R. A., dan I. M. Sukartha 2013. Pengaruh Ukuran Perusahaan, Kinerja Keuangan dan Eksposur Media pada Pengungkapan Informasi Lingkungan. E-Jurnal Akuntansi 4 (1): 1-17.

Hahn, R., dan M. Kühnen. 2013. Determinants of Sustainability Reporting: A Review of Results, Trends, Theory, and Opportunities in an Expanding Field of Research. Journal of Cleaner Production 59: 5-21.

Hariati, I., dan Y. W. Rihatiningtyas. 2015. Pengaruh Tata Kelola Perusahaan dan Kinerja Lingkungan Terhadap Nilai Perusahaan. Simposium Nasional Akuntansi XVIII Medan. 16-19 September: 1-16.

Jensen, M. C. dan W. H. Meckling. 1976. Theory of the Firm: Managerial Behavior, Agency Costs and Ownership Structure. Journal of Financial Economics 3 (4): 305-360.

Karokaro, $\quad$ A. $\quad$ S., $\quad 2018 . \quad$ WALHI: Kondisi Indonesia Masih Darurat Ekologis. [Online] Available at: http://www.mongabay.co.id/2018/04/24/walhi-kondisi-indonesia-masihdarurat-ekologis/ 
Keputusan Ketua Badan Pengawas Pasar Modal Dan Lembaga Keuangan Nomor: Kep431/Bl/2012 Tentang Penyampaian Laporan Tahunan Emiten Atau Perusahaan Publik. Badan Pengawas Pasar Modal dan Lembaga Keuangan. Jakarta.

Koran Kompas. 2017. Kerusakan Lingkungan Masif. 20 Maret. Halaman 1. Jakarta.

Laksmi, A. C., dan Z. Kamila. 2018. The Effect of Good Corporate Governance and Earnings Management to Corporate Social Responsibility Disclosure. Academy of Accounting and Financial Studies Journal 22 (1): 1-16.

Millstein, I. A. 1991. The Responsibility of the Institutional Investor in Corporate Management. In A.W. Sametz (ed.) The Battle for Corporate Control: Shareholder Rights, Stakeholder Interests, and Managerial Responsibilities. Homewood, IL: Business One Irwin.

Murwaningsari, E. 2009. Hubungan Corporate Governance, Corporate Social Responsibilities dan Corporate Financial Performance dalam Satu Continum. Jurnal Akuntansi dan Keuangan 11 (1): 30-41.

Oktafianti, D., dan A. Rizki. 2015. Pengaruh Kepemilikan Manajerial, Ukuran Perusahaan dan Kinerja Keuangan Terhadap Corporate Environmental Disclosure Sebagai Bentuk Tanggung Jawab Sosial dalam Laporan Tahunan (Studi pada Perusahaan Peserta Proper 2011-2013). Seminar Nasional Akuntansi XVIII Medan 16-19 September.

Plumlee, M., D. Brown, R. M. Hayes, dan R. S. Marshall. 2015. Voluntary Environmental Disclosure Quality and Firm Value: Further Evidence. Journal of Accounting and Public Policy 34(4) 336-361.

Prasetianti, N. 2014. Pengaruh Media dan Struktur Corporate Governance terhadap Kualitas Environmental Disclosure. Skripsi. Universitas Diponegoro. Semarang.

Purwanto, A. 2011. Pengaruh Tipe Industri, Ukuran Perusahaan, Profitabilitas terhadap Corporate Social Responsibility. Jurnal Akuntansi dan Auditing 8(1): 1-94.

Radhouane, I., M. Nekhili, H. Nagati, dan G. Paché. 2018. The Impact of Corporate Environmental Reporting on Customer-Related Performance and Market Value. Management Decision 56(7): 1630-1659.

Rebecca, Y., dan S. V. Siregar. 2012. Pengaruh Corporate Governance Index, Kepemilikan Keluarga, dan

Kepemilikan Institusional terhadap Biaya Ekuitas dan Biaya Utang: Studi Empiris pada Perusahaan Manufaktur yang Terdaftar di BEI. Simposium Nasional Akuntansi XV Banjarmasin 20-23 September: 1-28.

Rupley, K. H., D. Brown, dan R. S. Marshall. 2012. Governance, Media and the Quality of Environmental Disclosure. Journal of Accounting and Public 31(6):610-640.

Safitri, N. F. W. 2013. Analisa Pelaporan Pengungkapan Corporate Social Responsibility (CSR) Berdasarkan Pedoman Global Reporting Initiatives (GRI). Jurnal Akuntansi UNESA 2(1): 1-18.

Sari, A. R., Sutrisno, dan E. G. Sukoharsono 2013. Pengaruh Kepemilikan Institusional, Komposisi Dewan 
Komisaris, Kinerja Perusahaan terhadap Luas Pengungkapan Corporate Social Responsibility di dalam Sustainability Report pada Perusahaan Manufaktur yang Terdaftar di BEI. Jurnal Aplikasi Manajemen 11(3): 481-491.

Solikhah, B., dan A. M. Winarsih. 2016. Pengaruh Liputan Media, Kepekaan Industri, dan Struktur Tata Kelola Perusahaan terhadap Kualitas Pengungkapan Lingkungan. Jurnal Akuntansi dan Keuangan Indonesia 13(1): 1-22.

Sukasih, A., dan E. Sugiyanto 2017. Pengaruh Struktur Good Corporate Governance dan Kinerja Lingkungan Terhadap Pengungkapan Corporate Social Responsibility (Studi Pada Perusahaan Manufaktur di Bursa Efek Indonesia Periode 20112015). Riset Akuntansi dan Keuangan Indonesia 2(2): 121-131.

Wahana Lingkungan Hidup Indonesia (WALHI). 2014. Tinjauan Lingkungan Hidup WALHI 2014. Politik 2014: Utamakan Keadilan Ekologis. Diunduh tanggal 21 November 2018, http://www.walhi.or.id.

Winarno, W.W., 2015. Analisis Ekonometrika dan Statistika dengan Eviews. Yogyakarta: UPP STIM YKPN.

Wiranata, Y. A., dan Y. W. Nugrahanti. 2013. Pengaruh Struktur Kepemilikan Terhadap Profitabilitas Perusahaan Manufaktur di Indonesia. Jurnal Akuntansi dan Keuangan 15(1): 15-26.

Wulandari, A. K., dan A. Puspaningsih. 2017. Analisis Determinan Corporate Social Responsibility (CSR) Disclosure di Indonesia. Simposium Nasional Akuntansi XX Jember. 27-30 September: 1-21.

Yanti, Y. (2015). Pengaruh Corporate Social Responsibility dan Environmental Performance Terhadap Kinerja Keuangan BUMN dan Non BUMN yang Terdaftar Di Bursa Efek Indonesia 2009-2012. Jurnal Akuntansi 19(2): 242 259. 